\title{
Prostaglandin $\mathbf{F}_{2 \alpha}$-stimulated phospholipase $\mathbf{D}$ activation in osteoblast-like MC3T3-E1 cells: involvement in sustained 1,2-diacylglycerol production
}

\author{
Takatoshi SUGIYAMA, ${ }^{\star} \ddagger$ Takayuki SAKAI, ${ }^{*}$ Yoshinori NOZAWA $†$ and Nobumitsu OKA ${ }^{\star}$ \\ Departments of * Oral and Maxillo-Facial Surgery and †Biochemistry, Gifu University School of Medicine, Tsukasamachi-40, Gifu 500, Japan
}

In $\left[{ }^{3} \mathrm{H}\right]$ myristic acid-labelled osteoblast-like MC3T3-E1 cells, prostaglandin $\mathrm{F}_{2 \alpha}\left(\mathrm{PGF}_{2 \alpha}\right)$-induced PLD activity was assessed by measuring the $\left[{ }^{3} \mathrm{H}\right]$ phosphatidylethanol (PEt) formation in the presence of ethanol. Inhibition of the increase in intracellular $\mathrm{Ca}^{2+}$ concentration $\left(\left[\mathrm{Ca}^{2+}\right]_{1}\right)$ by $\mathrm{U} 73122$, an inhibitor of phosphoinositide-specific phospholipase C (PI-PLC), or chelation of extracellular $\mathrm{Ca}^{2+}$ with EGTA or of intracellular $\mathrm{Ca}^{2+}$ with BAPTA, suppressed PGF $_{2 \alpha}$-induced phospholipase D (PLD) activation. Neither protein kinase $C$ (PKC) inhibitors nor PKC down-regulation with phorbol 12-myristate 13-acetate affected $\mathrm{PGF}_{2 \alpha}$-induced [ $\left.{ }^{3} \mathrm{H}\right] \mathrm{PEt}$ formation. In permeabilized cells, guanosine $5^{\prime}-[\gamma$-thio $]$ triphosphate enhanced $\mathrm{PGF}_{2 \alpha}$ 's potency in $\left[{ }^{3} \mathrm{H}\right] \mathrm{PEt}$ formation in the presence of $\mathrm{Ca}^{2+}$. The pretreatment of intact cells with pertussis toxin failed to inhibit $\mathrm{PGF}_{2 \alpha^{-}}$ induced $\left[{ }^{3} \mathrm{H}\right] \mathrm{PEt}$ formation. $\mathrm{PGF}_{2 \alpha}$ caused a biphasic production of $\left[{ }^{3} \mathrm{H}\right] 1,2$-diacylglycerol $\left(\left[{ }^{3} \mathrm{H}\right] 1,2-D A G\right)$ in $\left[{ }^{3} \mathrm{H}\right]$ glycerol-labelled cells. The initial transient phase was decreased by U73122, whereas the late sustained phase was decreased by ethanol and the phosphatidic acid phosphohydrolase inhibitor, propranolol. From these results, it was suggested that PGF $_{2 \alpha}$-induced PLD activation was mediated by the dual control of the $\left[\mathrm{Ca}^{2+}\right]_{1}$ increase due to PI-PLC activation and activation of pertussistoxin-insensitive G-protein, but not mediated by PKC, and also that PLD activation was involved in the late sustained 1,2-DAG generation in MC3T3-E1 cells.

\section{INTRODUCTION}

There has been substantial evidence for the agonist-induced activation of phospholipase D (PLD; EC 3.1.4.4) in a variety of mammalian cells [1,2]. This enzyme catalyses not only the hydrolysis of phospholipids, producing phosphatidic acid (PA) and the free polar group, but also the transphosphatidylation reaction [3]. In the presence of ethanol, the activity of PLD specifically produces phosphatidylethanol (PEt) by the latter reaction [4]. It was shown by measuring reaction products that PLD activation caused by the agonist(s), e.g. hormones, growth factors and cytokines, was associated with activation of protein kinase $\mathrm{C}$ (PKC) [5-7], increase in intracellular free $\mathrm{Ca}^{2+}$ concentration $\left(\left[\mathrm{Ca}^{2+}\right]_{1}\right)[8-11]$ and/or increase in GTP-binding protein (G-protein) $[11,12]$. In fact, in several types of cells PLD is activated by the PKC activator phorbol 12-myristate 13-acetate (PMA) [13], $\mathrm{Ca}^{2+}$ ionophore [8,14] or GTP analogue [14,15], and inhibited by PKC down-regulation [16,17], PKC inhibitors (H-7 [18], staurosporine [19], Ro-31-8220 [17]), the intracellular- $\mathrm{Ca}^{2+}$ chelator BAPTA [8], the phosphoinositide-specific phospholipase C (PI-PLC) inhibitor U73122 [8] and inactive analogues of guanine nucleotides (GDP or its $\beta$-thio analogue $[14,15])$. Furthermore, in many cases of the agonist-induced PLD activation, it was suggested that the PLD activation occurred downstream of PI-PLC activation [8,20-22]. However, the PKC-independent pathway for PLD activation was also observed to operate in some cell types $[6,23]$.

Prostaglandins (PGs) are important local factor(s) not only in bone resorption but also its formation [24-26] by both paracrine and autocrine mechanism(s). It was suggested by previous investigators that some effects of PG(s) were mediated by the activation of adenylate cyclase, and others were mediated by the stimulation of PtdIns $(4,5) P_{2}$ hydrolysis by PLC $[25,27,28]$. $\mathrm{PGF}^{2 \alpha}$, a potent proliferating agonist for osteoblasts, causes activation of PI-PLC leading to increased $\left[\mathrm{Ca}^{2+}\right]_{1}$ and PKC activation in some cloned cells [28-31], including osteoblast-like MC3T3-E1 cells [25,32].

Recently, in addition to 1,2-diacylglycerol (1,2-DAG) produced by PtdIns $(4,5) P_{2}$ hydrolysis, other sources of $1,2-$ DAG are proposed, i.e. phosphatidylcholine (PC) hydrolysis by PLD and/or PLC [22,33-37]. PLD activation results in the production of PA, which is then dephosphorylated by PA phosphohydrolase (EC 3.1.3.4) to produce 1,2-DAG. Such PC-derived 1,2-DAG produces a sustained phase of agonist-induced 1,2-DAG formation. Prolonged 1,2-DAG formation [29] and PKC activation [30] were observed in fibroblasts stimulated by $\mathrm{PGF}_{2 \alpha}$, indicating the presence of cross-talk between PLD and PI-PLC pathways [8]. In osteoblast(-like) cells, activation of $\operatorname{PtdIns}(4,5) P_{2}$ hydrolysis by PLC [27], PKC activation and/or increase in $\left[\mathrm{Ca}^{2+}\right]_{\mathrm{i}}$ [28] were elicited by hormones, growth factors and cytokines, including PGs $[25,27]$. But there is no report of agonist-induced PLD activation in osteoblastic cells.

In the present study, we have investigated the activation of PLD, its regulatory mechanism and the involvement of the enzyme in 1,2-DAG production in $\mathrm{PGF}_{2 \alpha}$-stimulated osteoblastlike MC3T3-E1 cells.

Abbreviations used: $\alpha$-MEM, $\alpha$-Modified Eagle's Minimum Essential Medium; BAPTA, 1,2-bis-(2-aminophenoxy)ethane-NNN $N^{\prime}$-tetra-acetic acid: BAPTA/AM, tetra-acetoxymethyl ester of BAPTA; $\left[\mathrm{Ca}^{2+}\right]_{\mathrm{i}}$, intracellular free $\mathrm{Ca}^{2+}$ concn.; FBS, fetal-bovine serum; fura-2, 1-[2-(5'-carboxyoxazol-2'-yl)6-aminobenzofuran-5-oxy]-2-(2'-amino-5'-methylphenoxy)-ethane- $N N N^{\prime} N^{\prime}$-tetra-acetic acid; fura-2/AM, penta-acetoxymethyl ester of fura-2; GTP[S] guanosine $5^{\prime}$-[ $\gamma$-thio]triphosphate; H-7, 1-(5-isoquinolinesulphonyl)-2-methylpiperazine dihydrochloride; PA, phosphatidic acid; PC, phosphatidylcholine; PEt, phosphatidylethanol; PGF ${ }_{2 \alpha}$, prostaglandin $\mathrm{F}_{2 \alpha}$; PI-PLC, phosphoinositide-specific phospholipase C; PLD, phospholipase D; PKC, protein kinase C; PMA, phorbol 12-myristate 13-acetate; U73122, 1-(6-\{[17 $\beta$-3-methoxyoestra-1,3,5(10)-trien-17-yl]amino\}hexyl)-1H-pyrrole-2,5-dione; 1,2-DAG, 1,2-diacylglycerol.

‡ To whom correspondence should be addressed. 


\section{MATERIALS AND METHODS}

\section{Materials}

PGF $_{2 \alpha}$ was kindly supplied from Ono Pharmaceuticals Co. (Osaka, Japan). PMA, ionomycin, propranolol, thapsigargin and BSA (fraction V) were obtained from Sigma Chemical Co. (St. Louis, MO, U.S.A.). The acetoxymethyl esters of fura-2 (fura-2/AM) and BAPTA (BAPTA/AM) (full systematic names given in title-page footnote) were obtained from Dojin Laboratories (Kumamoto, Japan). 1-(\{6[17 $\beta$-3-Methoxyoestra-1,3,5(10)trien-17-yl]amino\}hexyl)-1 $H$-pyrrole-2,5-dione (U73122) was generously given by Dr. John E. Bleasdale, The Upjohn Co. (Kalamazoo, MI, U.S.A.). 1-(5-Isoquinolinesulphonyl)-2methylpiperazine dihydrochloride (H-7) was purchased from Seikagaku Kogyo Co. (Tokyo, Japan). Calphostin C and K-252a were purchased from Kyouwa Hakkou Co. (Tokyo, Japan). $\alpha$ Modified Eagle's Minimum Essential Medium ( $\alpha$-MEM) and fetal bovine serum (FBS) were obtained from Gibco Laboratories (Grand Island, MY, U.S.A.) and Flow Laboratories (Dublin, VA, U.S.A.) respectively. $\left[1(3)-{ }^{3} \mathrm{H}\right]$ Glycerol $(37-110 \mathrm{GBq} / \mathrm{mmol})$ and $\left[9,10(\mathrm{n}){ }^{3} \mathrm{H}\right]$ myristic acid $(1.5-2.2 \mathrm{TBq} / \mathrm{mmol})$ were purchased from Amersham International (Amersham, Bucks., U.K.). All other reagents used were of analytical grade.

\section{Cell culture}

Cloned MC3T3-E1 cells were kindly supplied by Dr. H. Kodama (Ohou University, Japan). The cells were cultured in $\alpha$-MEM supplemented with $10 \% \mathrm{FBS}$ at $37^{\circ} \mathrm{C}$ under an atmosphere of $5 \% \mathrm{CO}_{2}$ in air. Cells were subcultured every 3 days as described by Kodama et al. [38].

\section{[ $\left.{ }^{3} \mathrm{H}\right]$ PEt formation In Intact MC3T3-E1 cells}

PLD activity was determined as previously described [10,23,39] by measuring $\left[{ }^{3} \mathrm{H}\right] \mathrm{PEt}$ produced via PLD-catalysed transphosphatidylation [20] in $\left[{ }^{3} \mathrm{H}\right]$ myristic acid-labelled cells. MC3T3-E1 cells were plated at a density of $2 \times 10^{4}$ cells/well on 6-well plates and cultured for 4 days. For metabolic labelling of phospholipids, cells were cultured for $12 \mathrm{~h}$ in $0.75 \mathrm{ml}$ of $\alpha$ $\mathrm{MEM}+0.3 \%$ BSA containing $1 \mu \mathrm{Ci}$ of $\left[{ }^{3} \mathrm{H}\right]$ myristic acid/well. Cells were washed twice in $1 \mathrm{ml}$ of $\mathrm{Ca}^{2+} / \mathrm{Mg}^{2+}$-free PBS, and then preincubated in Hepes buffer (25 mM NaHepes, pH 7.4, $120 \mathrm{mM}$ $\mathrm{NaCl}, 5 \mathrm{mM} \mathrm{KCl}, 1 \mathrm{mM} \mathrm{MgCl}, 1 \mathrm{mM} \mathrm{CaCl}_{2}, 10 \mathrm{mM}$ glucose and $0.1 \%$ BSA) containing ethanol $(1 \%, v / v)$ at $37^{\circ} \mathrm{C}$ for $5 \mathrm{~min}$ with or without the indicated reagents. After preincubation, cells were stimulated with $\mathrm{PGF}_{2 \alpha}(10 \mathrm{pM}-10 \mu \mathrm{M})$, ionomycin $(2 \mu \mathrm{M})$, A23187 $(1 \mu \mathrm{M})$ or thapsigargin $(1 \mu \mathrm{M})$ in $1 \mathrm{ml}$ of Hepes buffer containing ethanol $(1 \%)$ for the indicated times. The reaction was then terminated by addition of $1.3 \mathrm{ml}$ of ice-cold methanol, and lipids were then extracted by the method of Bligh and Dyer [40]. $\left[{ }^{3} \mathrm{H}\right] \mathrm{PEt}$ was separated from other phospholipids by twodimensional t.l.c. on silica gel 60 plates. The first solvent system was chloroform/methanol $/ 28 \% \mathrm{NH}_{3}(65: 35: 6$, by vol.) and the second was chloroform/acetone/methanol/acetic acid/water (6:8:2:2:1, by vol.). The area corresponding to PEt was scraped off the plate and radioactivity was measured in liquid-scintillation counter.

\section{[ $\mathrm{H}$ HPEt formation in digitonin-permeabilized MC3T3-E1 cells}

MC3T3-E1 cells were grown and labelled with $\left[{ }^{3} \mathrm{H}\right]$ myristic acid in 6-well plates as described above. The cells were washed in $1 \mathrm{ml}$ of $\mathrm{Ca}^{2+} / \mathrm{Mg}^{2+}$-free PBS twice, and then incubated in potassium glutamate buffer (20 mM Pipes, $\mathrm{pH} 6.9,139 \mathrm{mM}$ potassium glutamate, $1 \mathrm{mM} \mathrm{MgCl}_{2}, 1 \mathrm{mM} \mathrm{Mg-ATP}$ and $5 \mathrm{mM}$ EGTA) containing $10 \mu \mathrm{M}$ digitonin at $25^{\circ} \mathrm{C}$ for $15 \mathrm{~min}$ as previously described [23,41]. Incubations were started by replacing the solution with $1 \mathrm{ml}$ of potassium glutamate buffer containing the indicated concentrations of free $\mathrm{Ca}^{2+}$ buffered with $1 \mathrm{mM}$ $\mathrm{CaCl}_{2} / 5 \mathrm{mM}$ EGTA in the presence of $1 \%$ ethanol and the test reagents (i.e. guanosine $5^{\prime}-[\gamma$-thio $]$ triphosphate (GTP[S]), GDP, $\mathrm{PGF}_{2 \alpha}$ etc. $\}$ at various concentrations for the indicated times. Incubations were terminated as described above and lipids were extracted by the method of Bligh and Dyer [40]. Then $\left[{ }^{3} \mathrm{H}\right] \mathrm{PEt}$ was separated by two-dimensional t.l.c. for radioactivity measurement.

\section{PGF $_{2 \alpha}$-induced [ ${ }^{3} \mathrm{H}$ ]1,2-DAG formation in intact MC3T3-E1 cells}

For metabolically labelling phospholipids, the cells were cultured in $0.75 \mathrm{ml}$ of $\alpha-\mathrm{MEM}+0.3 \%$ BSA containing $2 \mu \mathrm{Ci}$ of $\left[{ }^{3} \mathrm{H}\right]$ glycerol/well for $36 \mathrm{~h}$. The cells were washed twice, and then incubations were started by replacing the buffer with $1 \mathrm{ml}$ of Hepes buffer containing the test reagents at various concentrations and for the indicated times. Incubations were terminated by addition of ice-cold methanol, and lipids were extracted by the method of Bligh and Dyer [40]. [ $\left.{ }^{3} \mathrm{H}\right] 1,2-D A G$ was separated by t.l.c. on silica gel 60 plates (pretreated with $0.4 \mathrm{M}$ borate) in the solvent system chloroform/acetone $(24: 1, \mathrm{v} / \mathrm{v})$.

\section{Measurement of $\left[\mathrm{Ca}^{2+}\right]_{1}$ in single cells}

The cells were plated at a density of $1 \times 10^{3}$ cells/well of the Flexiperm-Disc (Heraeus Biotechnologie, Hanau, Germany) in $\alpha$ MEM containing $10 \%$ FBS and cultured for $72 \mathrm{~h}$. Then the cells were labelled with fura-2/AM, and $\left[\mathrm{Ca}^{2+}\right]_{i}$ changes by each reagent were measured for single cells by using a fluorescence image analyser (ARGUS-100/CA; Hamamatsu Photonics Corp, Hamamatsu, Japan) as previously described [42].

\section{RESULTS}

\section{PGF $_{2 \alpha}$-Induced PLD activation in MC3T3-E1 cells}

To investigate PLD activity, we measured the accumulation of $\left[{ }^{3} \mathrm{H}\right] \mathrm{PEt}$ produced by transphosphatidylation activity in the presence of ethanol. [ $\left.{ }^{3} \mathrm{H}\right]$ Myristic acid was observed to be incorporated to a large extent into PC of intact MC3T3-E1 cells, up to over $70 \%$ during incubation for $36 \mathrm{~h}$ (Table 1). The [ $\left.{ }^{3} \mathrm{H}\right]$ myristic acid-labelled cells were washed and preincubated for 5 min with Hepes buffer containing $1 \%$ ethanol, and then stimulated. [ $\left.{ }^{3} \mathrm{H}\right] \mathrm{PEt}$ was increased by addition of $1 \mu \mathrm{M} \mathrm{PGF}_{2 \alpha}$, reaching a plateau by about $2 \mathrm{~min}$ (Figure 1). The $\mathrm{PGF}_{2 \alpha^{-}}$ induced $\left[\mathrm{Ca}^{2+}\right]_{1}$ increase (insert in Figure 1) was concurrent with an initial $\left[{ }^{3} \mathrm{H}\right] \mathrm{PEt}$ increase. For a $5 \mathrm{~min}$ incubation, $\mathrm{PGF}_{2 \alpha}$ $(1 \mathrm{nM}$ to $1 \mu \mathrm{M})$ produced an increase in $\left[{ }^{3} \mathrm{H}\right] \mathrm{PEt}$ in a dosedependent fashion (results not shown). The profile for $\left[{ }^{3} \mathrm{H}\right] \mathrm{PEt}$ formation was similar to that for the $\left[\mathrm{Ca}^{2+}\right]_{1}$ increase (T. Sakai and T. Sugiyama, unpublished work) and inositol phosphate(s) production previously described in MC3T3-E1 cells [27].

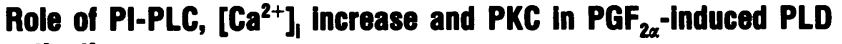 activation}

In some cell types, including MC3T3-E1 cells, PGF $_{2 \alpha}$ was observed to activate PtdIns $(4,5) P_{2}$ hydrolysis, which in turn caused an increase in $\left[\mathrm{Ca}^{2+}\right]$ and activation of PKC [28-31]. The agonist-induced PI-PLC activation occurring before PLD activation has been reported in many studies $[5,7-10,16,17,43]$. If 


\section{Table 1 Distribution of ['H]myristic acid radioactivity in major phosphollpids and 1,2-DAG of MC3T3-E1 cells}

MC3T3-E1 cells were incubated with $\left.{ }^{3} \mathrm{H}\right]$ myristic acid $(1 \mu \mathrm{Ci} /$ well for $12 \mathrm{~h})$, then cells were washed twice with $\mathrm{Ca}^{2+} / \mathrm{Mg}^{2+}$-free PBS and incubated in Hepes buffer with or without $1 \mu \mathrm{M}$ PGF in $1 \%$ ethanol for $5 \mathrm{~min}$. Total cellular lipids were extracted and analysed by t.l.c. as described in the Materials and methods section. Total radioactivity of $\left.{ }^{3} \mathrm{H}\right] \mathrm{m}$ mristic acid-labelled lipid (per culture well) was $685490 \pm 49315$ d.p.m. Data represent means \pm S.D. $(n=3)$ : *significantly different from the control value $(P<0.01)$. Abbreviation: PE, phosphatidylethanolamine.

\begin{tabular}{|c|c|c|c|}
\hline \multirow[b]{3}{*}{ Cellular lipids } & \multicolumn{3}{|c|}{$\left[{ }^{3} \mathrm{H}\right]$ Myristic acid incorporation } \\
\hline & \multicolumn{2}{|l|}{ Control } & \multirow{2}{*}{$\frac{1 \mu \mathrm{M} \mathrm{PGF}_{2 \alpha}}{(\% \text { of total })}$} \\
\hline & Radioactivity (d.p.m.) & (\% of total) & \\
\hline PA & $3523 \pm 644$ & $0.51 \pm 0.02$ & $1.11 \pm 0.12^{*}$ \\
\hline PC & $517550 \pm 23650$ & $75.5 \pm 3.45$ & $72.1 \pm 4.6$ \\
\hline PE & $47234 \pm 5756$ & $6.91 \pm 0.13$ & $5.94 \pm 0.22^{\star}$ \\
\hline PEt & $3427 \pm 910$ & $0.49 \pm 0.12$ & $1.03 \pm 0.04^{\star}$ \\
\hline Inositol plus serine phospholipids & $27776 \pm 3705$ & $4.06 \pm 0.03$ & $3.17 \pm 0.33^{*}$ \\
\hline Lyso-PC & $6032 \pm 206$ & $0.88 \pm 0.03$ & $0.85 \pm 0.01$ \\
\hline Sphingomyelin & $62791 \pm 6375$ & $9.16 \pm 0.93$ & $10.49 \pm 0.47$ \\
\hline 1,2-DAG & $4891 \pm 177$ & $0.83 \pm 0.03$ & $2.73 \pm 0.28^{*}$ \\
\hline
\end{tabular}

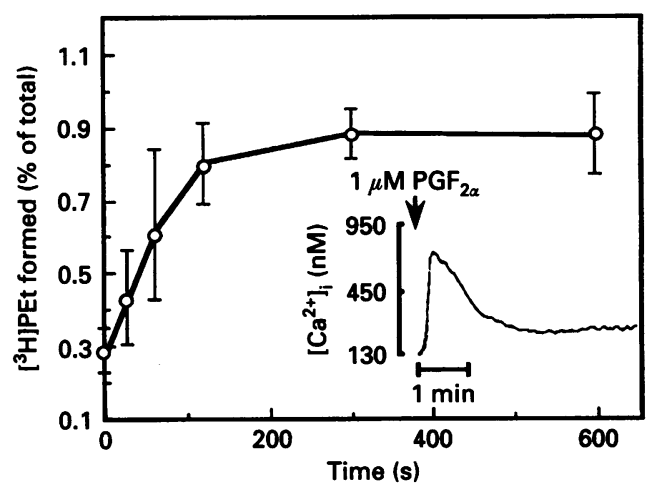

Figure 1 Time course of production of ['H]PEt in response to $\mathrm{PGF}_{2 \alpha}$ in MC3T3-E1 cells

$\left[{ }^{3} \mathrm{H}\right]$ Myristic acid-labelled MC3T3-E1 cells were stimulated for the indicated times with $1 \mu \mathrm{M}$ $\mathrm{PGF}_{2 \alpha}$ in $1 \%$ ethanol. The lipid samples were then analysed by two-dimensional t.l.c. for $\left[^{3} \mathrm{H}\right] \mathrm{PEt}$ as described in the Materials and methods section. The radioactivity in the controls was: PC, 428387 d.p.m.; PEt, 2617 d.p.m. Data are means \pm S.E.M. from three experiments. The insert shows a trace of the $\mathrm{PGF}_{2 a}$-induced $\left[\mathrm{Ca}^{2+}\right]_{1}$ response in fura-2-labelled MC3T3-E1 cells. The cells were loaded as described in the Materials and methods section and stimulated with $1 \mu \mathrm{M}$ $\mathrm{PGF}_{2 \alpha}$ at the arrow. $\left[\mathrm{Ca}^{2+}\right]_{1}$ was calculated with a fluorescence image analyser ARGUS-100/CA.

PGF $_{2 \alpha}$-induced PLD activation is secondary to PI-PLC activation, then it would be expected that prevention of $\mathrm{PGF}_{2 \alpha^{-}}$ induced PI-PLC activation inhibits PLD activation. As shown in Table 2, pretreatment for $20 \mathrm{~min}$ with the PLC inhibitor U73122 $[8,44]$ markedly decreased not only the $\left[\mathrm{Ca}^{2+}\right]_{1}$ increase $\mathrm{PGF}_{2 \alpha^{-}}$ induced but also the $\mathrm{PGF}_{2 \alpha}$-induced $\left[{ }^{3} \mathrm{H}\right] \mathrm{PEt}$ formation. These results indicate that inhibition of PGF $_{2 \alpha}$-induced PI-PLC activation leads to decreased PLD activation, as reported in other cells [8].

Then we examined how PtdIns $(4,5) P_{2}$ hydrolysis is coupled to PLD activation. Some investigators $[8-10,34]$ have proposed that the $\left[\mathrm{Ca}^{2+}\right]_{\mathrm{i}}$ increase resulting from PI-PLC activation is required for PLD activation, and others [16-19,34] reported involvement of PKC after PI-PLC activation. To examine the role of the $\left[\mathrm{Ca}^{2+}\right]_{1}$ increase, we investigated the effect of the prevented $\left[\mathrm{Ca}^{2+}\right]_{1}$ increase and also the agonist-independent $\left[\mathrm{Ca}^{2+}\right]_{1}$ increase on $\mathrm{PGF}_{2 \alpha}$-induced PLD activation. As shown in Table 2, chelation
Table 2 Involvement of PI-PLC and $\left[\mathrm{Ca}^{2+}\right]_{1}$ increase in PGF $2{ }_{2 \alpha}$-induced PLD activation in MC3T3-E1 cells

For measurement of $\left[{ }^{3} \mathrm{H}\right] \mathrm{PEt}$ accumulation, $\left[{ }^{3} \mathrm{H}\right]$ myristic acid-labelled MC3T3-E1 cells were washed twice with $\mathrm{Ca}^{2+} / \mathrm{Mg}^{2+}$-free PBS, then preincubated in Hepes buffer with or without $2 \mu \mathrm{M}$ U73122 or $10 \mu \mathrm{M}$ BAPTA/AM for 20 or $60 \mathrm{~min}$ respectively. During the last $5 \mathrm{~min}$ of the treatment, the buffer was changed to $1 \%$ ethanol-supplemented buffer with or without (EGTA and BAPTA/AM) $1 \mathrm{mM} \mathrm{CaCl}$, and stimulated with each agonist for $5 \mathrm{~min}$. The reactions were then stopped by addition of ice-cold methanol, and the lipid samples were analysed by twodimensional t.l.c. for $\left[{ }^{3} \mathrm{H}\right] \mathrm{PEt}$ as described in the Materials and methods section. The radioactivity in the controls was: PC, 500313 d.p.m.; PEt, 2469 d.p.m. For measurement of $\left[\mathrm{Ca}^{2+}\right]_{\mathrm{j}}$, the cells were plated at a density of $1 \times 10^{3} \mathrm{cell} / \mathrm{s} /$ well on the Flexiperm-Disc. After culture for $72 \mathrm{~h}$, the cells were loaded with fura-2/AM (in some samples, $2 \mu \mathrm{M}$ U73122 or $10 \mu \mathrm{M}$ BAPTA/AM was added and incubated for 20 or $60 \mathrm{~min}$ respectively), and then the $\left[\mathrm{Ca}^{2+}\right]$, change was monitored and calculated with an image analyser ARGUS-100/CA. The values express the peak $\left[\mathrm{Ca}^{2+}\right]_{1}$ increase by $\mathrm{PGF}_{2 \alpha}$. Data are means \pm S.D. for $n$ experiments. The pretreatment with U73122 or EGTA gave no significant changes in basal $\left[\mathrm{Ca}^{2+}\right]_{\mathrm{i}}$ (control, $115.2 \pm 35.2 \mathrm{nM}$; U73122, $138 \pm 32.4 \mathrm{nM}$; EGTA, $131 \pm 45.8 \mathrm{nM}$ ), and BAPTA/AM decreased basal $\left[\mathrm{Ca}^{2+}\right]_{1}(73 \pm 44.4 \mathrm{nM})$. Abbreviation: N.D., not determined.

\begin{tabular}{|c|c|c|}
\hline & $\begin{array}{l}{\left[\mathrm{Ca}^{2+}\right]_{\mathrm{i}} \text { Increase }} \\
\text { (\% of basal) }\end{array}$ & $\begin{array}{l}{\left[{ }^{3} \mathrm{H}\right] \text { PEt formed }} \\
\text { (\% of basal) }\end{array}$ \\
\hline Control (1 $\mu \mathrm{M} \mathrm{PGF}_{2 \alpha}$ ) & $384 \pm 145(n=23) \dagger$ & $353 \pm 104(n=22) \dagger$ \\
\hline $\begin{array}{l}\text { Pretreated with } \\
1 \mu \mathrm{M} \text { U73122 } \\
0.5 \mathrm{mM} \text { EGTA } \\
10 \mu \mathrm{M} \text { BAPTA/AM }\end{array}$ & $\begin{array}{l}134 \pm 59(n=20)^{\star} \\
187 \pm 101(n=25)^{\star} \\
109 \pm 23(n=7)^{\star}\end{array}$ & $\begin{array}{l}183 \pm 32(n=5) \dagger \\
185 \pm 27(n=8) \dagger \\
169 \pm 28(n=5) \dagger\end{array}$ \\
\hline $\begin{array}{l}2 \mu \mathrm{M} \text { lonomycin } \\
1 \mu \mathrm{M} \text { A23187 } \\
1 \mu \mathrm{M} \text { Thapsigargin }\end{array}$ & $\begin{array}{l}418 \pm 57(n=7) \dagger \\
\text { N.D. } \\
453 \pm 70(n=6) \dagger\end{array}$ & $\begin{array}{l}161 \pm 85(n=14)^{*} \\
131 \pm 26(n=3)^{*} \\
107 \pm 31(n=8)^{*}\end{array}$ \\
\hline
\end{tabular}

of extracellular $\mathrm{Ca}^{2+}$ (no added $\mathrm{Ca}^{2+}$ and in the presence of $0.5 \mathrm{mM}$ EGTA) and intracellular $\mathrm{Ca}^{2+}(10 \mu \mathrm{M}$ BAPTA/AM) diminished $\mathrm{PGF}_{2 \alpha}$-induced $\left[\mathrm{Ca}^{2+}\right]_{1}$ increases in fura-2-loaded single cells and markedly inhibited PLD activation. Therefore the $\left[\mathrm{Ca}^{2+}\right]_{1}$ rise was thought to play a crucial role in $\mathrm{PGF}_{2 \alpha^{-}}$ induced PLD activation. In order to ascertain further the implication of $\left[\mathrm{Ca}^{2+}\right]_{1}$ in PLD activation, we examined whether or not receptor-independent $\left[\mathrm{Ca}^{2+}\right]_{1}$ increases could mimic the $\mathrm{PGF}_{2 \alpha}$-induced PLD activation. The $\left[\mathrm{Ca}^{2+}\right]_{1}$ increases caused by 
Table 3 Effects of PKC inhibitors and PKC down-regulation on PGF induced PLD activation in MC3T3-E1 cells

For PKC down-regulation, $\left[{ }^{3} \mathrm{H}\right]$ myristic acid-labelled MC3T3-E1 cells were preincubated with $330 \mathrm{nM}$ PMA for $24 \mathrm{~h}$, and for PKC inhibition the cells were preincubated for 20 min in Hepes buffer with PKC inhibitors. During the last 5 min of the treatment, the buffer was changed to 1\%-ethanol-supplemented, and stimulated with $1 \mu \mathrm{M} \mathrm{PGF}_{2 \alpha}$ for $5 \mathrm{~min}$. The reactions were then stopped by addition of ice-cold methanol, and the lipid samples were analysed by twodimensional t.l.c. for $\left[{ }^{3} \mathrm{H}\right] \mathrm{PEt}$ as described in the Materials and methods section. The radioactivity in the controls was: $P C, 553580$ d.p.m.; PEt, 2108 d.p.m. Data are means \pm S.D. for $n$ experiments.

$\left[{ }^{3} \mathrm{H}\right] \mathrm{PEt}$ formed (\% of basal)

$\begin{array}{ll}\text { Control }\left(1 \mu \mathrm{M} \mathrm{PGF}_{2 \alpha}, 2 \mathrm{~min}\right) & 318 \pm 104(n=15) \\ \text { Pretreated with } & \\ \text { H-7 }(50 \mu \mathrm{M}) & 407 \pm 56(n=6) \\ \text { Calphostin C }(2 \mu \mathrm{M}) & 451 \pm 173(n=5) \\ \text { K-252a }(1 \mu \mathrm{M}) & 446 \pm 58(n=3) \\ \text { Staurosporine }(0.1 \mu \mathrm{M}) & 287 \pm 23(n=3) \\ \text { PKC-down-regulated }(330 \mathrm{nM} \text { PMA, 24 h) } & 250 \pm 43(n=7)\end{array}$

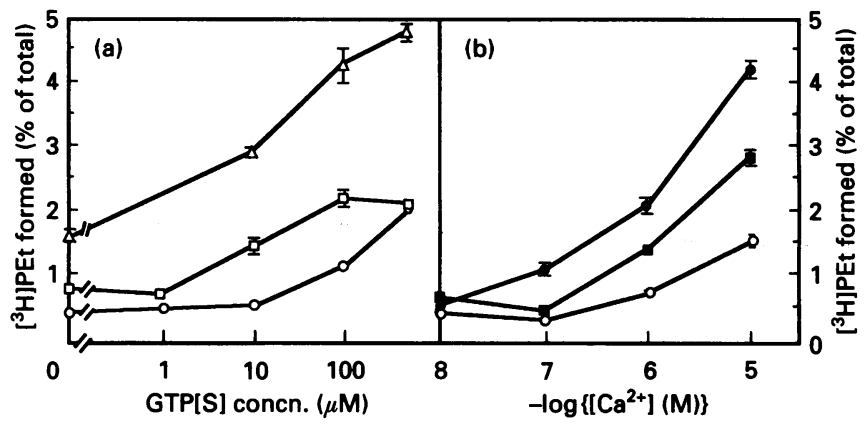
Figure 2 Synergistic activation of PLD by $\mathrm{Ca}^{2+}$ and GTP[S] in permeabilized
MC3T3-E1 cells

$\left[{ }^{3} \mathrm{H}\right]$ Myristic acid-labelled MC3T3-E1 cells were permeabilized with $10 \mu \mathrm{M}$ digitonin at $25^{\circ} \mathrm{C}$ for $15 \mathrm{~min}$ as described in the Materials and methods section, then incubated with the indicated concentrations of GTP[S] in the presence of $\mathrm{Ca}^{2+}$-EGTA-buffered solution containing $1 \%$ ethanol at $37^{\circ} \mathrm{C}$ for $30 \mathrm{~min}$. (a) $\mathrm{O}, \mathrm{pCa} 7 ; \square, \mathrm{pCa} ; \triangle$, pCa5; (b) $\square, 10 \mu \mathrm{M}$ GTP[S]; - $100 \mu \mathrm{M}$ GTP[S]; O, $0 \mu \mathrm{M}$ GTP[S]. The radioactivity in the controls (pCa8; $0 \mu \mathrm{M}$ GTP[S]) was: PC, 507761 d.p.m.; PEt, 2807 d.p.m. Data are means \pm S.E.M. from two experiments.

ionomycin and thapsigargin were larger than that with $\mathrm{PGF}_{2 \alpha}$ stimulation. However, $\left[{ }^{3} \mathrm{H}\right] \mathrm{PEt}$ formation was much less with either treatment, compared with $\mathrm{PGF}_{2 \alpha}$-induced $\mathrm{PEt}$ production. This suggested that the $\mathrm{Ca}^{2+}$ increase was needed, but it alone was not sufficient, for PGF $_{2 \alpha}$-induced PLD activation, and additional factor(s) is required for its full activation. A likely candidate is $\mathrm{PKC}$ activated via $\operatorname{PtdIns}(4,5) P_{2}$ hydrolysis. Thus $\left[{ }^{3} \mathrm{H}\right] \mathrm{PEt}$ formation was examined in cells pretreated with PKC inhibitors or exposed to long-term PMA treatment to downregulate $\mathrm{PKC}$ activity. Although a $\mathrm{PKC}$ inhibitor, $\mathrm{H}-7$, inhibited PKC activity in MC3T3-E1 cells [42], $\mathrm{PGF}_{2 \alpha}$-induced $\left[{ }^{3} \mathrm{H}\right] \mathrm{PEt}$ formation was unaffected by this inhibitor. Other PKC inhibitors, $\mathrm{K}-252 \mathrm{a}$ [45], calphostin C [46], and staurosporine, also did not decrease the $\left[{ }^{3} \mathrm{H}\right] \mathrm{PEt}$ production (Table 3 ). In cells with PKC down-regulated by incubation with $330 \mathrm{nM}$ PMA for $24 \mathrm{~h}$ [42], there was apparently no significant inhibitory effect on $\mathrm{PGF}_{2 \alpha^{-}}$ induced PLD activation.

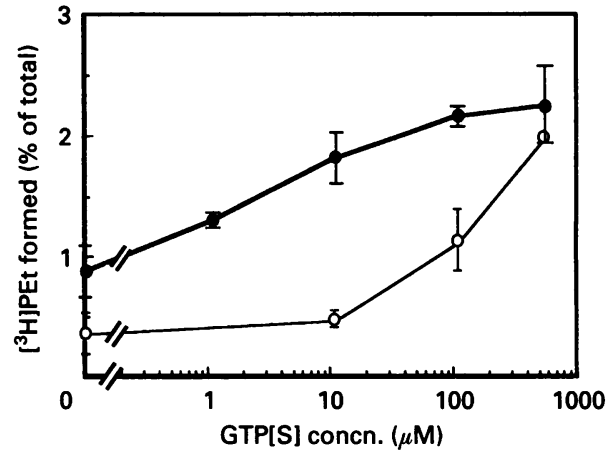

Figure 3 Effect of GTP[S] on PGF $_{2 \alpha}$-induced PLD activation in permeabilized
MC3T3-E1 cells

$\left[{ }^{3} \mathrm{H}\right]$ Myristic acid-labelled MC3T3-E1 cells were permeabilized with $10 \mu \mathrm{M}$ digitonin at $25^{\circ} \mathrm{C}$ for $15 \mathrm{~min}$ as described in the Materials and methods section, then incubated with the indicated concentration of GTP[S] with (O) or without (O) $1 \mu \mathrm{M} \mathrm{PGF}_{2 \alpha}$ at pCa7 containing $1 \%$ ethanol at $37^{\circ} \mathrm{C}$ for $30 \mathrm{~min}$. The radioactivity in the controls was: PC, 488288 d.p.m.; PEt, 1666 d.p.m. Data are means \pm S.E.M. from two experiments.

\section{Effects of guanosine phosphate analogues on PGF ${ }_{2 \alpha}$-Induced PLD activation in permeabllized cells}

Several studies have reported the implication of G-protein in agonist-induced PLD activation in some types of cells $[11,12,14,15]$. In our preliminary experiment, $\mathrm{NaF}$, a potent $\mathrm{G}$ protein-activating factor, stimulated the PLD activity as observed in PGF $_{2 \alpha}$-induced intact cells (results not shown). As the Gprotein-activating factors $\mathrm{NaF}$ and the unhydrolysable GTP analogue, GTP[S], also stimulated PI-PLC [47] in these cells, which caused a $\left[\mathrm{Ca}^{2+}\right]_{1}$ change, we investigated the roles of $\mathrm{G}$ protein in $\mathrm{PGF}_{2 \alpha}$-induced PLD activation in the permeabilized cells. In a $\left[\mathrm{Ca}^{2+}\right]_{1}$-buffered condition, addition of GTP[S] to cells led to a significant dose-dependent increase in $\left[{ }^{3} \mathrm{H}\right] \mathrm{PEt}$ formation in the presence of $1 \%$ ethanol and physiological concentration of $\mathrm{Ca}^{2+}$ (Figure 2). Further, the activation of PLD activity was $\mathrm{Ca}^{2+}$-dependent, and $\mathrm{Ca}^{2+}$ alone in the absence of GTP[S] produced an increase in $\left[{ }^{3} \mathrm{H}\right] \mathrm{PEt}$ level, but significantly lower than in its presence. At $10 \mu \mathrm{M}$ and $100 \mu \mathrm{M}$ GTP[S], the PLD activity was enhanced at physiological $\mathrm{Ca}^{2+}$ concentration in a dose-dependent manner (Figure 2b). These data indicated that $\mathrm{Ca}^{2+}$ and GTP[S] exert a synergistic action on PLD activation. In the presence of $100 \mathrm{nM} \mathrm{Ca}{ }^{2+}$, which is the $\left[\mathrm{Ca}^{2+}\right]_{\mathrm{i}}$ level in the resting cells, PGF $_{2 \alpha}$-mediated PLD activation was enhanced by addition of GTP[S] in the medium (Figure 3 ). Increase of $\mathrm{Ca}^{2+}$ to $1 \mu \mathrm{M}$, which is nearly equivalent to the $\mathrm{PGF}_{2 \alpha}$-induced $\left[\mathrm{Ca}^{2+}\right]_{1}$ level, shifted the plot of $\left[{ }^{3} \mathrm{H}\right] \mathrm{PEt}$ formation to the left (results not shown). To ascertain the involvement of G-protein, we used GDP, which is known to inhibit the PLD activity induced by GTP[S] [14,15]. As shown in Figure 4, the PLD activation caused by $100 \mu \mathrm{M}$ GTP[S] was considerably decreased by addition of $1 \mathrm{mM}$ GDP. The inhibitory effect of GDP was also observed in PGF $_{2 \alpha}$-stimulated cells, but its extent was smaller. Pretreatment of intact MC3T3-E1 cells with pertussis toxin $(300 \mathrm{ng} / \mathrm{ml})$ for $12 \mathrm{~h}$ failed to suppress the PLD activity by PGF $_{2 \alpha}(369 \pm 196 \%$ increase from basal; mean \pm S.D., $n=4)$. Under this condition, the $\alpha$ subunit(s) of the pertussis-toxin substrate(s) was ADP-ribosylated, as described in our previous report [47]. These results suggest that pertussistoxin-insensitive G-protein may be involved in $\mathrm{PGF}_{2 \alpha}$-induced PLD activation. 


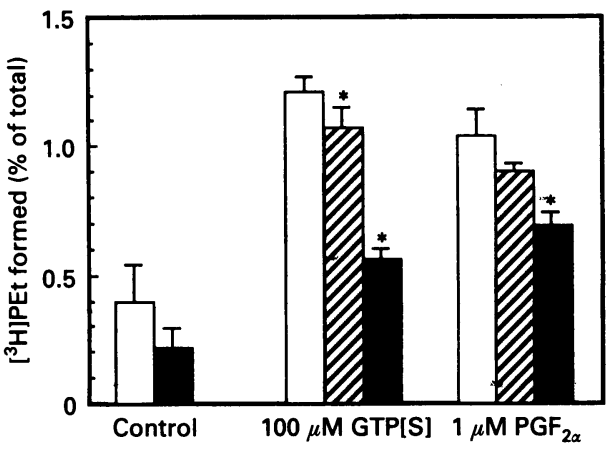

Figure 4 Inhibitory effect of GDP on GTP[S]- and PGF ${ }_{2 x}$-induced PLD activation in permeabilized MC3T3-E1 cells

$\left[{ }^{3} \mathrm{H}\right]$ Myristic acid-labelled MC3T3-E1 cells were permeabilized as described in the Materials and methods section, then stimulated with $100 \mu \mathrm{M}$ GTP[S] or $1 \mu \mathrm{M} \mathrm{PGF}_{2 \alpha}$ in the presence of indicated concentrations of GDP at pCa7 containing $1 \%$ ethanol at $37^{\circ} \mathrm{C}$ for $30 \mathrm{~min}$. $\square$, No GDP (controls); $\square$, with $100 \mathrm{mM} \mathrm{GDP;} \boldsymbol{\square}$, with $1 \mathrm{mM}$ GDP. Data are means \pm S.E.M. from two experiments: *significant difference from non-treated cells $(P<0.05)$.

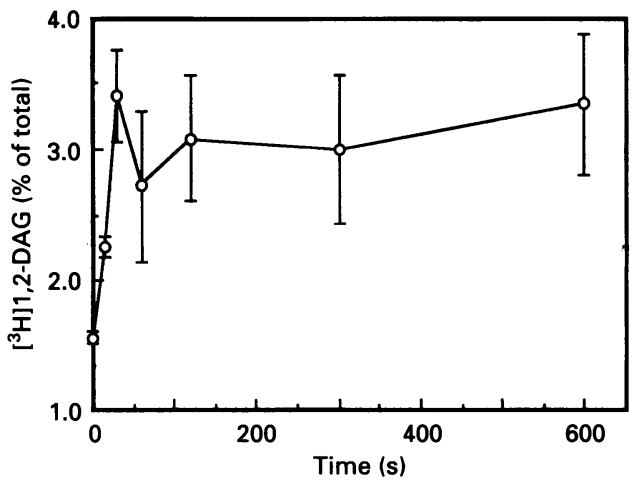

\section{Figure 5 Time course of $\mathrm{PGF}_{2 \alpha}$-stimulated [3 $\left.\mathrm{H}\right] 1,2-\mathrm{DAG}$ formation in MC3T3-E1 cells}

$\left[{ }^{3} \mathrm{H}\right] \mathrm{Glycerol}-$ labelled MC3T3-E1 cells were stimulated for the indicated times with $1 \mu \mathrm{M} \mathrm{PGF}_{2 \alpha}$. $\left[{ }^{3} \mathrm{H}\right] 1,2-\mathrm{DAG}$ was separated by t.I.c. in the solvent system chloroform/acetone $(24: 1, \mathrm{v} / \mathrm{v})$. Data are means \pm S.E.M. from three experiments. The radioactivity in total lipids was $315751 \pm 35790$ d.p.m./well, and the distribution in other lipids at $0 \mathrm{~s}$ was: $\mathrm{PA}, 6.29 \pm 0.73 \%$. PC, $47.22 \pm 0.77 \%$; inositol plus serine phospholipids, $13.07 \pm 0.08 \%$; phosphatidylethanolamine, $14.67 \pm 0.87 \%$; lyso-PC, $1.00 \pm 0.03 \%$; $1,2-\mathrm{DAG}, 1.56 \pm 0.2 \%$.

\section{Role of PLD in PGF $_{2 \alpha}$-induced sustained 1,2-DAG formation}

We have examined the role of PLD activation by PGF $_{2 \alpha}$ in the sustained production of 1,2-DAG. Figure 5 shows the time course of PGF $_{2 \alpha}$-induced 1,2-DAG formation in MC3T3-E1 cells. When the cells prelabelled with $\left[{ }^{3} \mathrm{H}\right]$ glycerol for $36 \mathrm{~h}$ were stimulated by $1 \mu \mathrm{M} \mathrm{PGF}_{2 \alpha}$, a supramaximal concentration for activation of both PI-PLC [27,28] and PLD, the increase in 1,2DAG was biphasic. The early phase of 1,2-DAG increase, to a peaking at $30 \mathrm{~s}$, was concurrent with the $\left[\mathrm{Ca}^{2+}\right]_{1}$ increase (see Figure 1) elicited by PI-PLC, and this initial phase was followed by a sustained increase in 1,2-DAG, which reached a plateau after $2 \mathrm{~min}$ and then remained elevated for the period examined $(10 \mathrm{~min})$. To ascertain that PLD activity acts in such $\mathrm{PGF}_{2 \alpha^{-}}$ induced 1,2-DAG production, we have examined the effects of
Table 4 Role of PLD activation in PGF -induced [ $\left.{ }^{3} \mathrm{H}\right] 1,2-\mathrm{DAG}$ formation in MC3T3-E1 cells

$\left.{ }^{3} \mathrm{H}\right]$ Glycerol-labelled MC3T3-E1 cells were stimulated with $1 \mu \mathrm{M}$ PGF for $30 \mathrm{~s}$ or 5 min with or without ethanol, propranolol or U73122. [ $\left.{ }^{3} \mathrm{H}\right] 1$,2-DAG was separated by t.I.c. in the solvent system chloroform/acetone $(24: 1, v / v)$. Data are means \pm S.E.M. from two experiments: N.D., not determined.

\begin{tabular}{cll}
\hline & \multicolumn{3}{l}{$\left[{ }^{3} \mathrm{H}\right] 1,2-\mathrm{DAG}(\%$ of control) } \\
\cline { 2 - 3 } & $30 \mathrm{~s}$ & $300 \mathrm{~s}$ \\
\hline $\begin{array}{c}\text { Control }(1 \mu \mathrm{M} \mathrm{PGF} \\
+ \text { Ethanol }\end{array}$ & 100 & 100 \\
$(0.2 \%)$ & & \\
$(0.5 \%)$ & $\mathrm{N} . \mathrm{D}$. & $78.8 \pm 22.0$ \\
$(1 \%)$ & $\mathrm{N} . \mathrm{D}$. & $78.3 \pm 0.86^{*}$ \\
+ Propranolol & $85.0 \pm 9.17$ & $74.2 \pm 2.40^{*}$ \\
$(10 \mu \mathrm{M})$ & & \\
$(50 \mu \mathrm{M})$ & $\mathrm{N} . \mathrm{D}$. & $71.3 \pm 24.0$ \\
$(200 \mu \mathrm{M})$ & $\mathrm{N} . \mathrm{D}$. & $70.3 \pm 2.70^{*}$ \\
$+\mathrm{U} 73122$ & $100 \pm 5.60$ & $64.3 \pm 2.40^{*}$ \\
$(2 \mu \mathrm{M})$ & & \\
No PGF & $38.1 \pm 12.2^{*}$ & N.D. \\
& 28.4 & 23.0
\end{tabular}

* Significantly different from non-treated cells $(P<0.05)$.

agents which inhibit PLD activity on 1,2-DAG production. Upon stimulation with $\mathrm{PGF}_{2 \alpha}$ in the presence of ethanol, 1,2DAG production in the second sustained phase was suppressed to about $70 \%$ of the control (Table 4). Furthermore, $200 \mu \mathrm{M}$ propranolol, a non-specific but selective inhibitor of PA phosphohydrolase [35,36], decreased the PGF $_{2 \alpha}$-induced 1,2-DAG production in the sustained phase, but did not affect the early-phase production (Table 4). The late 1,2-DAG production was decreased to $75 \%$ and $65 \%$ of the control in the presence of ethanol ( $1 \%)$ and propranolol $(200 \mu \mathrm{M})$ respectively. In contrast, the early phase of 1,2-DAG production in response to $\mathrm{PGF}_{2 \alpha}$ was markedly decreased by the PI-PLC inhibitor, but was unchanged by ethanol and propranolol.

\section{DISCUSSION}

In the present study, we demonstrated for the first time the PGF $_{2 \alpha}$-induced activation of PLD (Figure 1). The initial rapid rise (first $1-2 \mathrm{~min}$ ) in metabolically stable $\left[{ }^{3} \mathrm{H}\right] \mathrm{PEt}$ was followed by the sustained elevation in $\mathrm{PGF}_{2 \alpha}$-stimulated cells. The same concentration of $\mathrm{PGF}_{2 \alpha}$ also caused a rapid and transient increase of $\left[\mathrm{Ca}^{2+}\right]_{\mathrm{i}}$ due to $\operatorname{Ins} P_{3}$ produced by PI-PLC activation. These results suggested the relationship between two $\mathrm{PGF}_{2 \alpha}$-activated signal pathways, PI-PLC/Ca ${ }^{2+}$ and PLD, as described in several reports $[7,8,10,16,17,19,22,34]$. Pretreatment of the cells with the PI-PLC inhibitor U73122 decreased both the PGF $_{2 \alpha}$-induced $\left[\mathrm{Ca}^{2+}\right]_{\mathrm{i}}$ increase and PLD activation. As demonstrated by other investigators [8-10,34], our data also indicated the requirement for a $\left[\mathrm{Ca}^{2+}\right]_{1}$ increase in $\mathrm{PGF}_{2 \alpha}$-induced PLD activation in MC3T3-E1 cells. Chelation of extra- and intra-cellular free $\mathrm{Ca}^{2+}$ with EGTA and BAPTA diminished the PGF ${ }_{2 \alpha}$-induced $\left[\mathrm{Ca}^{2+}\right]_{\mathrm{i}}$ increase and $\left[{ }^{3} \mathrm{H}\right] \mathrm{PEt}$ production (Table 2 ). These results suggest that $\mathrm{PGF}_{2 \alpha}$-induced PLD activation requires a $\left[\mathrm{Ca}^{2+}\right]_{1}$ increase due to PtdIns $(4,5) P_{2}$ hydrolysis by PI-PLC. Although the $\left[\mathrm{Ca}^{2+}\right]_{1}$ increases by $\mathrm{Ca}^{2+}$ ionophores (ionomycin and $\mathrm{A} 23187$ ) or $\mathrm{Ca}^{2+}$ ATPase blocker (thapsigargin) were greater than that by PGF $_{2 \alpha}$, PLD activation was much lower than that with PGF $_{2 \alpha}$ stimulation. These receptor-independent $\left[\mathrm{Ca}^{2+}\right]_{i}$ increases could not mimic the $\mathrm{PGF}_{2 \alpha}$-induced PLD activation. Therefore $\left[\mathrm{Ca}^{2+}\right]_{\mathrm{i}}$ is 
required, but is not sufficient by itself and other factor(s) may act to fulfil PLD activation. PKC is a likely candidate as one of the factors. The short (5 min) treatment with PMA $(1 \mu \mathrm{M})$, a potent PKC activator, increased PLD activity in MC3T3-E1 cells (results not shown), as observed in other cells $[8,13,14,16,17,23,43]$. However, pretreatment with PKC inhibitors (H-7, calphostin C, K-252a and staurosporine) and PKC down-regulation by chronic PMA exposure did not prevent the PLD activation mediated by $\mathrm{PGF}_{2 \alpha}$. Thus $\mathrm{PGF}_{2 \alpha}$-induced activation of PLD may involve a PKC-independent pathway in these cells.

Since PLD activation (i) was stimulated by PGF $_{2 \alpha}$ in digitoninpermeabilized cells at the physiological range $(100 \mathrm{nM}-1 \mu \mathrm{M})$ of $\mathrm{Ca}^{2+}$, (ii) showed synergistic action of $\mathrm{PGF}_{2 \alpha}$ and GTP[S], and (iii) was inhibited by GDP, G-protein is strongly suggested to be involved in PGF ${ }_{2 \alpha}$-induced PLD activation. This G-protein was a pertussis-toxin-insensitive type. Taken together, it was indicated that PLD activation was elicited by a synergistic action of $\left[\mathrm{Ca}^{2+}\right]_{i}$ and G-protein, but largely independent of PKC in $\mathrm{PGF}_{2 \alpha^{-}}$ stimulated MC3T3-E1 cells.

Next, we have examined the involvement of PLD activation in the sustained 1,2-DAG production via the PLD/PA phosphohydrolase pathway $[22,35,37]$ in $\mathrm{PGF}_{2 \alpha}$-stimulated cells. In MC3T3-E1 cells, PGF $_{2 \alpha}$-induced [ $\left.{ }^{3} \mathrm{H}\right] 1$,2-DAG generation showed a biphasic increase: an initial rapid phase $(\sim 60 \mathrm{~s})$ and a subsequent sustained phase. In the present study, the initial phase of 1,2-DAG formation was concurrent with the $\left[\mathrm{Ca}^{2+}\right]_{i}$ increase and it was suppressed by addition of the PI-PLC inhibitor U73122, suggesting that the initial 1,2-DAG is derived from phosphoinositide hydrolysis via PLC. On the other hand, addition of ethanol or propranolol to inhibit PLD/PA phosphohydrolase decreased the sustained phase of 1,2-DAG formation. The same treatments were without effect on the initial 1,2-DAG phase. PLD activation alone cannot explain the sustained phase of PGF ${ }_{2 \alpha}$-induced 1,2-DAG formation; nearly one-third of total 1,2-DAG is produced via the PLD pathway. An alternative route for the sustained generation of 1,2-DAG has been thought to result from PC hydrolysis by PLC in several cell types [5,43]. Our preliminary study showed production of $\left[{ }^{3} \mathrm{H}\right]$ phosphocholine in $\left[{ }^{3} \mathrm{H}\right]$ choline-labelled MC3T3-E1 cells stimulated with PGF $_{2 \alpha}$, thus suggesting an involvement of PC-PLC. Investigations are in progress to determine the differential contribution of the PLD and PC-PLC pathways in the late sustained elevation of 1,2DAG in PGF $_{2 \alpha}$-stimulated MC3T3-E1 cells.

This study was supported in part by a Grant-in-Aid for Scientific Research from the Ministry of Education, Science and Culture of Japan. We greatly appreciate Dr. John E. Bleasdale, The Upjohn Co. (Kalamaz00, MI, U.S.A.) for kindly providing U73122.

\section{REFERENCES}

1 Löffelholz, K. (1989) Biochem. Pharmacol. 38, 1543-1549

2 Billah, M. M. and Anthes, J. C. (1990) Biochem. J. 269, 281-291

3 Yang, S. F., Freer, S. and Benson, A. A. (1967) J. Biol. Chem. 242, 477-481

4 Kobayashi, M. and Kanfer, J. N. (1987) J. Neurochem. 48, 1597-1603
5 Martinson, E. A., Goldstein, D. and Brown, J. H. (1989) J. Biol. Chem. 264, 14748-14754

6 Llahi, S. and Fain, J. N. (1992) J. Biol. Chem. 267, 3679-3685

7 Fu, T., Okano, Y. and Nozawa, Y. (1992) Biochem. J. 283, 347-354

8 We, H., James-Kracke, M. R. and Halenda, S. P. (1992) Biochemistry 31, 3370-3377

9 Halenda, S. P. and Rehm, A. G. (1990) Biochem. J. 267, 479-483

10 Liu, Y., Geisbuhler, B. and Jones, A. W. (1992) Am. J. Physiol. 262, C941-C949

11 Anthes, J. C., Eckel, S., Siegel, M. I., Egan, R. W. and Billah, M. M. (1989) Biochem. Biophys. Res. Commun. 163, 657-664

12 Bocckino, S. B., Blackmore, P. F., Wilson, P. B. and Exton, J. H. (1987) J. Biol. Chem. 262, 15309-15315

13 Haung, C. and Cabot, M. C. (1990) J. Biol. Chem. 265, 14858-14863

14 Geny, B. and Cockcroft, S. (1992) Biochem. J. 284, 531-538

15 Hurst, K. M., Hughes, B. P. and Barritt, G. J. (1990) Biochem. J. 272, 749-753

16 MacNulty, E. E., Plevin, R. and Wakelam, M. J. O. (1990) Biochem. J. 272, 761-766

17 Cook, S. J., Briscoe, C. P. and Wakelam, M. J. O. (1991) Biochem. J. 280, 431-438

18 Kester, M., Simonson, M. S., McDermott, R. G., Baldi, E. and Dunn, M. J. (1992) J. Cell. Physiol. 150, 578-585

19 Huang, C. and Cabot, M. C. (1990) J. Biol. Chem. 265, 17468-17473

20 Exton, J. H. (1990) J. Biol. Chem. 265, 1-4

21 Qian, Z. and Drewes, L. R. (1991) FASEB J. 5, 315-319

22 Matozaki, T. and Williams, J. A. (1989) J. Biol. Chem. 264, 14729-14734

23 Kanoh, H., Kanaho, Y. and Nozawa, Y. (1992) J. Neurochem. 59, 1786-1794

24 Dietrich, J. W., Goodson, J. M. and Raisz, L. G. (1975) Prostaglandins 10, 231-240

25 Hakeda, Y., Yoshino, T., Nakatani, Y., Kurihara, N., Maeda, N. and Kumegawa, M. (1986) J. Cell. Physiol. 128, 155-161

26 Raisz, L. G., Alander, C. B., Fall, P. M. and Simmons, H. A. (1990) Endocrinology (Baltimore) 126, 1076-1079

27 Hakeda, Y., Hotta, T., Kurihara, N., Ikeda, E., Maeda, N., Yagyu, Y. and Kumegawa, M. (1987) Endocrinology (Baltimore) 121, 1966-1974

28 Yamaguchi, D. T., Hahn, T. J., Beeker, T. G., Kleemans, C. R. and Muallen, S. (1988) J. Biol. Chem. 263, 10745-10753

29 Fukami, K. and Takenawa, T. (1989) J. Biol. Chem. 264, 14985-14989

30 Goin, M. and de Asua, L. J. (1992) FEBS Lett. 297, 175-178

31 Endo, T., Watanabe, H., Yamamoto, H., Tanaka, S. and Hasimoto, M. (1992) J. Endocrinol. 133, 451-458

32 Hakeda, Y., Harada, S., Matsumoto, T., Tezuka, K., Higashino, K., Kodama, H., Hashimoto-Goto, T., Ogata, E. and Kumegawa, M. (1991) J. Biol. Chem. 266, 21044-21050

33 Pai, J.-K., Siegel, M. I., Egan, R. W. and Billah, M. M. (1988) Biochem. Biophys. Res. Commun. 150, 355-364

34 Lin, P. and Gilfillan, A. M. (1992) Eur. J. Biochem. 207, 163-168

35 Chabot, M. C., McPhail, L. C., Wykle, R. L., Kennerly, D. A. and McCall, C. E. (1992) Biochem. J. 286, 693-699

36 Purkiss, J. R. and Boarder, M. R. (1992) Biochem. J. 287, 31-36

37 Dinh, T. T. and Kennerly, D. A. (1991) Cell Regul. 2, 299-309

38 Kodama, H., Amagai, Y., Sudo, S., Kasai, S. and Yamamoto, S. (1981) Jpn. J. Oral Biol. 23, 899-901

39 Yamada, K., Kanaho, Y., Miura, K. and Nozawa, Y. (1991) Biochem. Biophys. Res. Commun. 175, 159-164

40 Bligh, E. A. and Dyer, W. J. (1959) Can. J. Biochem. Physiol. 37, 911-917

41 Peppers, S. C. and Holz, R. W. (1986) J. Biol. Chem. 261, 14665-14669

42 Sakai, T., Okano, Y., Nozawa, Y. and Oka, N. (1992) Cell Calcium 13, 329-340

43 Price, B. D., Morris, J. D. H. and Hall, A. (1989) Biochem. J. 264, 509-515

44 Smallridge, R. C., Kiang, J. G., Gist, I. D., Fein, H. G. and Galloway, R. J. (1992) Endocrinology (Baltimore) 131, 1883-1888

45 Kase, H., Iwahashi, K., Nakanishi, S., Matsuda, Y., Yamada, K., Takahashi, M., Murakata, C., Sato, A. and Kaneko, M. (1987) Biochem. Biophys. Res. Commun. 142, $436-440$

46 Kobayashi, E., Nakano, H., Morimoto, M. and Tamaoki, T. (1989) Biochem. Biophys. Res. Commun. 159, 548-553

47 Banno, Y., Sakai, T., Kumada, T. and Nozawa, Y. (1993) Biochem. J. 292, 401-408

Received 14 June 1993/7 October 1993; accepted 1 November 1993 